\title{
KILKA REFLEKSJI NA TEMAT REDUKCJI OBCIĄŻEŃ ADMINISTRACYJNYCH W PRAWIE OCHRONY ŚRODOWISKA
}

\section{SOME REFLECTIONS ON REDUCING ADMINISTRATIVE BURDENS IN ENVIRONMENTAL LAW}

\section{STRESZCZENIE}

Ochrona dobra wspólnego, za jakie należy uznać środowisko, wymaga obciążenia podmiotów korzystających z zasobów naturalnych pewnymi ciężarami i świadczeniami publicznymi. W ostatnim czasie skala obciążeń administracyjnych uzasadnionych ochroną środowiska znacznie jednak wzrosła, co miało negatywny wpływ na prowadzenie działalności gospodarczej i wymusiło podjęcie stosownej interwencji

" Magister, asystent w Katedrze Prawa Zarządzania Środowiskiem, Katolicki Uniwersytet Lubelski Jana Pawła II. 
prawodawcy. Celem artykułu było wskazanie mankamentów przyjętych zmian regulacji $\mathrm{w}$ zakresie opłat za korzystanie ze środowiska oraz związanych z nimi obowiązków informacyjnych, a także próba oceny ich skutków.

\section{Słowa kluczowe}

Prawo ochrony środowiska, obciążenia administracyjne, opłaty środowiskowe, obowiązki informacyjne.

\section{ABSTRACT}

The concept of common good protection, on example of environmental protection, requires from users of environmental goods tolerance for certain public burdens. In recent times the scale of administrative burdens set out in environmental law has increased significantly. This fact undoubtedly had a negative impact on economic activity and enforced appropriate legislative intervention. The aim of the article was to present the flaws of the amendments introduced to environmental law act related to the environmental fees and disclosure requirements, as well as an attempt to critical evaluation of their effects.

\section{Keywords}

Environmental law, administrative burdens, environmental fees, disclosure obligations.

\section{WPROWADZENIE}

Faktyczna kondycja polskiego rynku funkcjonowania przedsiębiorstw ma niebagatelny wpływ na całokształt sytuacji społeczno-gospodarczej kraju. Szczególnego znaczenia nabiera ona chociażby ze względu na udział w wypracowaniu wzrostu PKB czy utrzymanie wysokiego poziomu zatrudnienia. Dlatego też $\mathrm{w}$ zasięgu zainteresowania prawodawcy pozostaje problem ograniczenia szeroko rozumianych, multidyscyplinarnych barier rozwoju przedsiębiorczości, wśród których - obok barier han- 
dlowych, podatkowych, budowlanych czy podatkowych - dużym stopniem uciążliwości charakteryzują się bariery prawne ${ }^{1}$.

Przyjmowane przez legislatora normy prawne regulują coraz to nowe obszary zagadnień. Poszerzający się horyzont zainteresowań prawodawcy stanowi przy tym jedno ze źródeł kryzysu legislacji, wyrażającego się między innymi w inflacji przepisów, a także zjawisku przeregulowania czy ogólnego nadmiaru przepisów, prowadząc w konsekwencji do spadku jakości i wartości stanowionego prawa².

Ta negatywna tendencja zauważalna jest również na gruncie prawa ochrony środowiska, podlegającego w ostatnim czasie procesowi intensywnej instrumentalizacji ${ }^{3}$ oraz postępującej dysharmonizacji względem prawa Unii Europejskiej ${ }^{4}$. Zauważyć należy, że wskazane przepisy, pomimo coraz bardziej wyraźnych zastrzeżeń doktryny ${ }^{5}$, traktuje się zwykle jako wyodrębniony i wyspecjalizowany dział prawa administracyjnego $0^{6}$. Podobnie główny ciężar działań podejmowanych na rzecz zachowania lub przywracania równowagi przyrodniczej wiąże się z działalnością państwa i pozostających w jego strukturze organów władz publicznych. Wobec tego trudnym do wyobrażenia pozostaje prawidłowy system ochrony środowiska bez odpowiednio sformułowanych i skutecznych przepisów prawa admi-

1 M. Starczewska-Krzysztoszek, Bariery rozwoju małych $i$ średnich przedsiębiorstw w Polsce, ,Infos” 2008, nr 4, s. 3.

2 P. J. Suwaj, O globalnym prawie administracyjnym $w$ kontekście rozrostu prawa administracyjnego, [w:] Kryzys prawa administracyjnego? Inflacja prawa administracyjnego, red. D. Kijowski, P. J. Suwaj, Warszawa 2012, s. 23.

3 A. Haładyj, O nadmiarze i braku $w$ zakresie prawnej regulacji udziatu społeczeństwa w ochronie środowiska, [w:] Kryzys prawa administracyjnego?, s. 195 i nast.

4 Z. Bukowski, Dysharmonizacja polskiego prawa ochrony środowiska z prawem unijnym na wybranych przykładach, [w:] Dekada harmonizacji w prawie ochrony środowiska, red. M. Rudnicki, A. Haładyj, K. Sobieraj, Lublin 2011, s. 21 i nast.

5 A. Haładyj, Czy prawo ochrony środowiska jest odrębna gatęzia prawa?, [w:] Historia magistra vitae. Księga jubileuszowa ku czci Profesora Jerzego Flagi, red. A. Dębiński, S. Wrzosek, K. Maćkowska, M. Kruszewska-Gagoś, Lublin 2007, s. 85-89.

6 B. Wierzbowski, B. Rakoczy, Prawo ochrony środowiska. Zagadnienia podstawowe, Warszawa 2010, s. 21-23. 
nistracyjnego oraz funkcjonujących w jego granicach, właściwie wykwalifikowanych i wyposażonych w uporządkowany i spójny katalog kompetencji organów administracji. To właśnie system regulacji prawnych decyduje jednak o rzeczywistej, jak i potencjalnej, a także pożądanej, ale i niechcianej aktywności nie tylko administracji, lecz i pozostałych podległych mu podmiotów ${ }^{8}$.

Stale powiększająca się grupa obowiązujących przepisów prawa ochrony środowiska wyznacza równocześnie coraz szerszy zakres publicznoprawnych świadczeń obciążających podmioty korzystające ze środowiska, wśród których szczególną pozycję zajmują przedsiębiorcy ${ }^{9}$. Aktywność przedsiębiorstw w ramach rozwijającej się gospodarki w dużym stopniu uzależnionej od stanu i zasobności poszczególnych elementów przyrodniczych jako dóbr naturalnych ma bowiem olbrzymi wpływ na środowisko, przesądzając o jego stanie i niejednokrotnie stanowiąc przyczynę jego dewastacji. Na mocy ogólnego upoważnienia konstytucyjnego prawodawca uprawniony jest jednak do ustalania pewnych ciężarów i świadczeń publicznych, do po-

7 Na temat negatywnych opinii dotyczących przyjętego modelu organizacji ochrony środowiska w Polsce zob. B. Rakoczy, Ustawa o udostępnianiu informacji o środowisku a koncepcja legislacyjna polskiego prawa ochrony środowiska, „Prawo i Środowisko” 2009, nr 1, s. 55; M. Górski, System organizacyjny administrowania sprawami ochrony środowiska $w$ Polsce - analiza krytyczna, [w:] Ocena modelu organizacji ochrony środowiska $w$ Polsce i na Słowacji, red. E. Ura, J. Stelmasiak, S. Pieprzny.

8 Z. Duniewska, W kwestii czynników kształtujących prawo administracyjne, [w:] Między tradycją a przyszłościa w nauce prawa administracyjnego. Księga jubileuszowa dedykowana Profesorowi Janowi Bociowi, Wrocław 2009, s. 116.

9 Zgodnie z ustawową definicją podmiotu korzystającego ze środowiska, przez to pojęcie należy rozumieć: a) przedsiębiorcę w rozumieniu art. 4 ustawy o swobodzie działalności gospodarczej, a także osoby prowadzące działalność wytwórczą w rolnictwie w zakresie upraw rolnych, chowu lub hodowli zwierząt, ogrodnictwa, warzywnictwa, leśnictwa i rybactwa śródlądowego oraz osoby wykonujące zawód medyczny w ramach indywidualnej praktyki lub indywidualnej specjalistycznej praktyki, b) jednostkę organizacyjną niebędącą przedsiębiorcą w rozumieniu ustawy o swobodzie działalności gospodarczej, c) osobę fizyczną niebędącą podmiotem, o którym mowa w lit. a, korzystającą ze środowiska w zakresie, w jakim korzystanie ze środowiska wymaga pozwolenia (art. 3 pkt 20 POŚ). 
noszenia których zobowiązany jest każdy podmiot podlegający kompetencji jurysdykcyjnej polskiego państwa (art. 84 Konstytucji $\mathrm{RP}^{10}$ ), a zmierzających do zabezpieczenia dobra wspólnego, jakim jest środowisko ${ }^{11}$. Również konstytucyjne wolności i prawa, w tym także swoboda podejmowania i prowadzenia działalności gospodarczej, zgodnie z zasadą proporcjonalności mogą podlegać ograniczeniu z uwagi na konieczne potrzeby ochrony środowiska (art. 31 ust. 3 Konstytucji RP).

Wydaje się przy tym, że stopień oddziaływania ustawowych wymogów środowiskowych na działalność przedsiębiorców jest nie mniejszy niż w przypadku choćby reżimu przepisów podatkowych. Wynika to zwłaszcza z dość licznego, a przy tym równie skomplikowanego i przez to zwykle nie do końca zrozumiałego dla przedsiębiorców katalogu prawnych obowiązków związanych z ochroną środowiska, przesądzających już nie tylko o możliwości (jak chociażby obowiązek uzyskania stosownej koncesji na podjęcie i prowadzenie działalności gospodarczej w zakresie wydobywania kopalin ze złoża ${ }^{12}$ ), ale i w zakresie (przykładowo obowiązek uzyskania pozwolenia na korzystanie ze środowiska w zakresie szczególnego korzystania $\mathrm{z}$ wód ${ }^{13}$ ) czy sposobie prowadzenia działalności gospodarczej (tytułem przykładu wskazać można obowiązki przedsiębiorcy związane z odpowiednim poziomem wydajności recyklingu zużytych baterii i akumulatorów kwasowo-ołowiowych ${ }^{14}$ ).

Niekiedy przedsiębiorca obciążany jest swoistą kaskadą uzasadnianych względami ochrony środowiska ciężarów publicznych. Wystarczy przykład dokonującego emisji do powietrza gazów lub pyłów przedsiębiorcy, zobowiązanego nie tylko

10 Konstytucja Rzeczypospolitej Polskiej z dnia 2 kwietnia 1997 r., Dz.U. Nr 78, poz. 483 ze zm., dalej jako: Konstytucja RP.

11 J. Sommer, Efektywność prawa ochrony środowiska i jej uwarunkowania - problemy udatności jego struktury, Wrocław 2005, s. 85.

12 Obowiązek wynikający z art. 21 ust. 1 ustawy z dnia 9 czerwca 2011 r. Prawo geologiczne i górnicze, Dz.U. Nr 163, poz. 981 ze zm.

13 Obowiązek przewidziany art. 122 ust. 1 pkt 1 ustawy z dnia 18 lipca 2001 r. Prawo wodne, tekst jedn. Dz.U. z 2012 r., poz. 145 ze zm.

14 Obowiązek wskazany art. 33 ust. 1 ustawy z dnia 24 kwietnia 2009 r. o bateriach i akumulatorach, Dz.U. Nr 79, poz. 666 ze zm. 
do uzyskania stosownego pozwolenia emisyjnego, ale objętego również obowiązkiem przeprowadzenia wstępnych, a następnie okresowych lub ciągłych pomiarów wielkości emisji i ich ewidencjonowania oraz przechowywania przez 5 lat od zakończenia roku, którego dotyczą, a także przedkładania wyników pomiarów właściwym organom ochrony środowiska. Co więcej, w pewnych prawem przewidzianych sytuacjach, upoważniony przez ustawę organ ochrony środowiska, kierując się własnym uznaniem, może nałożyć kolejne, dodatkowe obowiązki (150 i 151 POŚ). W dalszym ciągu aktualne pozostają również postanowienia nakładające szczegółowe obowiązki opłatowe i sprawozdawcze.

Niekorzystną z punktu widzenia podmiotów korzystających ze środowiska tendencją systemu prawa ochrony środowiska jest zwłaszcza rozbudowanie wchodzących w jego skład regulacji, jak również wysoki stopień zmienności obowiązującego już prawodawstwa. Dokonywane częstokroć zmiany istniejących już bądź dopiero co wprowadzonych, a w skrajnych przypadkach nawet oczekujących jeszcze na wejście w życie przepisów, prowadzi do destabilizacji całego systemu, zmniejszając równocześnie jego przejrzystość ${ }^{15}$.

Równocześnie szczególne znaczenie wykorzystywanych w prawie ochrony środowiska norm o charakterze technicznym czy ekonomicznym wymusza coraz większą wewnętrzną specjalizację tego działu prawa. Stwarza to tym samym sytuacje, $\mathrm{w}$ których przepisy te nie są zintegrowane $\mathrm{z}$ normami zakorzenionymi w innych gałęziach systemu prawa, pozostając skomplikowanymi i niezrozumiałymi nie tylko dla przeciętnego obywatela, ale i mającego stosować je przedsiębiorcy ${ }^{16}$.

Należy również zauważyć, że część instytucji prawnych, pomimo ich powiązania $\mathrm{z}$ pewnymi obciążeniami administracyjnymi, znajdującymi często praktyczne uzasadnienie i z tego względu obdarzonych społecznym zrozumieniem, obrastając

15 A. Haładyj, K. Sobieraj, Uwagi na 30-lecie prawa ochrony środowiska, [w:] Prawo dla środowiska, red. A. Erechemla, Rzeszów 2011, s. 153-156.

16 M. Górski, [w:] Prawo ochrony środowiska, red. M. Górski, Warszawa 2009, s. 38. 
w nieuzasadnione czy możliwe do pominięcia instrumentalne obowiązki i procedury, z czasem staje się nazbyt skomplikowanymi, tracąc tym samym swe społeczne poparcie ${ }^{17}$.

Powyższe względy powodują, że duże nadzieje wiąże się z każdorazowymi planami ograniczenia formalizmu procedur i odciążenia przedsiębiorców od nadmiaru obciążeń publicznoprawnych, zwłaszcza w dobie ogólnoświatowego kryzysu. Dotrzymywanie publicznoprawnych obowiązków niejednokrotnie przysparza przedsiębiorcom nadmiernych, często nieuzasadnionych kosztów, hamując wzrost przedsiębiorczości i tym samym rozwój całej gospodarki. Dlatego też polski prawodawca, będąc świadomym niedoskonałości przyjmowanych przepisów, braku precyzji regulacji i biurokratycznych ograniczeń podjął w ostatnich latach wysiłki zmierzające do poprawy warunków wykonywania działalności gospodarczej ${ }^{18}$.

Od pewnego już czasu zaobserwować można aktywność legislacyjną Ministerstwa Gospodarki podejmującego wysiłki na rzecz poprawy warunków prowadzenia działalności gospodarczej w Polsce. Uprzednio ten projektodawca przyczynił się do wprowadzenia do obrotu prawnego ustawy z dnia 25 marca 2011 r. o ograniczaniu barier administracyjnych dla obywateli i przedsiębiorców ${ }^{19}$ oraz ustawy z dnia 16 września 2011 r. o redukcji niektórych obowiązków obywateli i przedsiębiorców ${ }^{20}$. Wraz z początkiem roku weszły w życie postanowienia nowej ustawy z dnia 16 listopada 2012 r. o redukcji niektórych obciążeń administracyjnych $\mathrm{w}$ gospodarce ${ }^{21}$, wdrażającej pakiet nowelizacji szesnastu ustaw, podobnie jak wcześniejsze mających za cel zmniejszenie nałożonych na przedsiębiorców obciążeń administracyjnych, niezależnie od przedmiotu prowadzonej

17 J. Zimmermann, Jedność prawa administracyjnego, [w:] Między tradycją a przyszłościa $w$ nauce prawa administracyjnego. Księga jubileuszowa dedykowana Profesorowi Janowi Bociowi, red. J. Supernat, Wrocław 2009, s. 819.

18 Uzasadnienie do projektu ustawy o redukcji niektórych obciążeń administracyjnych w gospodarce, druk sejmowy nr 833, dalej jako: Uzasadnienie projektu ustawy.

19 Dz.U. z 2011 r., Nr 106, poz. 622 ze zm.

20 Dz.U. z 2011 r., Nr 232, poz. 1378.

21 Dz.U. z 2012 r., poz. 1342, dalej jako: UROA. 
przez nich działalności. Najważniejsze zmiany wprowadzone tą ustawą dotyczyły wprawdzie podatku od towarów i usług oraz podatków dochodowych, jednak część z nich odnosiła się również do ograniczenia obowiązków powstających w związku z korzystaniem ze środowiska.

\section{REDUKCJA NIEKTÓRYCH OBCIĄŻEŃ ZWIĄZANYCH Z OBOWIĄZKIEM OPŁATOWYM}

Wśród nich szczególną uwagę ustawodawcy zwrócił obowiązek uiszczania opłat za korzystanie ze środowiska i powodowane w nim zmiany. Są one przymusowymi świadczeniami pieniężnymi, o przymusowym i ekwiwalentnym charakterze, pobieranymi w związku z korzystaniem z zasobów środowiskowych, w których wysokości wyrażona jest (lub przynajmniej powinna być) wycena poszczególnych komponentów środowiska $^{22}$. Kwestią sporną w literaturze pozostaje charakter prawny opłat. W przeważającej części doktryna przychyla się do zakwalifikowania ich jako rodzaj daniny publicznej ${ }^{23}$, jednakże spotkać można również stanowisko, iż jest to rodzaj podatku ekologicznego ${ }^{24}$.

Obowiązek opłatowy związany jest z korzystaniem ze środowiska wykraczającym poza ramy korzystania powszechnego i zgodnie z art. 273 ust. 1 POŚ ${ }^{25}$ jest ponoszony w sytuacji, kiedy podmiot wykorzystuje przysługującą mu prawną możliwość (wolność lub innego rodzaju uprawnienie) wprowadzania ga-

22 B. Draniewicz, Problem konstytucyjności opłat za korzystanie ze środowiska, „Państwo i Prawo” 2007, nr 7, s. 79; J. Małecki, Prawnofinansowe instrumenty ochrony i kształtowania środowiska, Poznań 1982, s. 17.

${ }^{23}$ K. Gruszecki, Opłaty za korzystanie ze środowiska $w$ prawie ochrony środowiska, „Glosa” 2003, nr 7, s. 4 i nast.

24 W. Fill, Charakter prawny opłat za korzystanie ze środowiska, [w:] Główne wyzwania $i$ problemy systemu finansów publicznych, red. J. Głuchowski, A. Pomorska, J. Szołno-Koguc, Lublin 2009, s. 459 i nast.

25 Ustawa z dnia 27 kwietnia 2001 r. Prawo ochrony środowiska, tekst jedn. Dz.U. z 2008 r., nr 25, poz. 150 ze zm., dalej jako: POŚ. 
zów lub pyłów do powietrza, wprowadzania ścieków do wód lub do ziemi, poboru wód bądź składowania odpadów ${ }^{26}$. Jednakże przypadki i zasady ponoszenia opłat za korzystanie ze środowiska określają również odrębne przepisy z zakresu prawa ochrony środowiska (art. 273 ust. 3 POŚ) ${ }^{27}$.

Z chwilą wejścia w życie ustawa Prawo ochrony środowiska wprowadziła system samonaliczania opłat przez przedsiębiorców (samoobciążania), oznaczający, że podmiot korzystający ze środowiska każdorazowo we własnym zakresie ustala wysokość należnej opłaty i wnosi ją na rachunek właściwego urzędu marszałkowskiego (art. 284 ust. 1 POŚ). Wiązało się to z następującą stopniowo zmianą krajowych technik opodatkowania podatkami i innymi daninami publicznymi, poprzez stosowanie zasady samoobliczenia należności przez podmioty zobligowane do ich uiszczania, bez wydawania $\mathrm{w}$ tej mierze decyzji konstytutywnych przez organy podatkowe ${ }^{28}$. Okres, za jaki podmiot korzystający ze środowiska naliczał należną opłatę i od którego końca rozpoczynał swój bieg miesięczny termin jej uiszczenia, początkowo wyznaczony jako kwartał, od 1 lipca 2005 r. $^{29}$ dotyczył półrocza, w którym rozpoczęło się korzystanie ze środowiska ${ }^{30}$.

26 T. Czech, Odpowiedzialność za opłaty podwyższone za korzystanie ze środowiska, „Zeszyty Naukowe Sądownictwa Administracyjnego” 2009, nr 6, s. 29 i nast.

27 Tytułem przykładu należy podać chociażby opłaty przewidziane przepisami ustawy z dnia 29 lipca 2005 r. o zużytym sprzęcie elektrycznym i elektronicznym, Dz.U. Nr 180, poz. 1495 ze zm. czy ustawy z dnia 3 lutego 1995 r. o ochronie gruntów rolnych i leśnych, tekst jedn. Dz.U. z 2005 r., Nr 121, poz. 1266 ze zm.

28 B. Draniewicz, Opłaty za korzystanie ze środowiska. Zarys analizy płaszczyzny prawnej, „Prawo i Środowisko” 2002, nr 1, s. 91 i nast.

29 Termin wyznaczony w związku z wejściem w życie ustawy z dnia 18 maja 2005 r. o zmianie ustawy - Prawo ochrony środowiska oraz niektórych innych ustaw, Dz.U. z 2005 r. Nr 113, poz. 954.

30 W wyniku kolejnych nowelizacji przepisów, ustawodawca przewidział pewne zróżnicowanie co do terminu wniesienia opłaty za korzystanie ze środowiska w przypadku opłaty zryczałtowanej za odprowadzanie ścieków pochodzących $\mathrm{z}$ chowu lub hodowli ryb innych niż łososiowate lub innych organizmów wodnych (termin 2 miesięcy od zakończenia cyklu produkcyjnego, za okres od dnia 1 maja roku rozpoczynającego cykl do dnia 30 kwietnia roku 
Znaczne przeobrażenia systemu opłatowego przewidziały regulacje wprowadzające $\mathrm{w}$ życie system zarządzania emisja$\mathrm{mi}^{31}$. W wyniku uchwalonych zmian nowe brzmienie otrzymały także przepisy art. 285 i 286 POŚ, różnicując równocześnie termin wyznaczony dla wypełnienia tego obowiązku w zależności od sposobu korzystania ze środowiska. Zgodnie z nowymi założeniami w przypadku wprowadzania ścieków do wód lub do ziemi, poboru wód oraz składowania odpadów podmiot korzystający ze środowiska winien wnieść opłatę do końca miesiąca następującego po upływie każdego półrocza (art. 285 ust. 2 POŚ). Z kolei termin uiszczenia opłaty za wprowadzanie gazów lub pyłów do powietrza ustalony został na koniec miesiąca następującego po upływie pierwszego półrocza oraz koniec lutego roku następnego za drugie półrocze, przy czym za pierwsze półrocze opłata wynosić ma 50\% rocznej opłaty za wprowadzanie gazów lub pyłów do powietrza uiszczonej w poprzednim roku kalendarzowym, a po drugim półroczu należną opłatę pomniejsza się o kwotę uiszczonej już opłaty za pierwsze półrocze (art. 285 ust. 3 i 5 POŚ).

Wprawdzie przeważająca część postanowień ustawy weszła w życie po upływie 30 dni od dnia jej ogłoszenia, jednak przepisy przejściowe (art. 62 USZE) przewidywały, że zmiana treści art. 285 i 286 nastąpi 1 stycznia 2010 r. Dalsze nowelizacje doprowadziły zaś do przesunięcia tego terminu kolejno na dzień 1 stycznia $2011 \mathrm{r}^{32}$ i 1 stycznia 2013 r. $^{33}$, by ostatecz-

następującego po zakończeniu cyklu) oraz w sytuacji, kiedy na składowisku odpadów umieszczono odpady oraz wydobyto z niego odpady tego samego rodzaju (termin do dnia 31 stycznia następnego roku).

31 Ustawa z dnia 17 lipca 2009 r. o systemie zarządzania emisjami gazów cieplarnianych i innych substancji, Dz.U. z 2009 r. Nr 130, poz. 1070 ze zm., dalej jako: USZE.

32 Art. 15 ustawy z dnia 20 listopada 2009 r. o zmianie ustawy - Prawo ochrony środowiska oraz niektórych innych ustaw, Dz.U. z 2009 r. Nr 215, poz. 1664, dalej jako: UZm1.

33 Art. 2 ustawy z dnia 3 grudnia 2010 r. o zmianie ustawy - Prawo ochrony środowiska oraz ustawy o systemie zarządzania emisjami gazów cieplarnianych i innych substancji, Dz.U. z 2010 r. Nr 249, poz. 1657, dalej jako: UZm2. 
nie ustalić datę wejścia w życie tych przepisów na 1 stycznia 2017 r. $^{34}$

W międzyczasie zamierzenia polskiego prawodawcy związane $\mathrm{z}$ uproszczeniem tak skonstruowanego systemu opłat znalazły swój wyraz w przepisach ustawy o redukcji niektórych obciążeń administracyjnych w gospodarce. Mocą jej postanowień po raz kolejny w dość istotny sposób przemodelowano obowiązujący system, dokonując korekty brzmienia przepisów art. 285 i 286 POŚ. I tak, od 1 stycznia 2013 r. ustawodawca jednolicie dla wszystkich sytuacji, w których aktualizuje się obowiązek opłatowy wynikający z faktu korzystania ze środowiska, ustalił termin uiszczenia publicznoprawnych należności, zachowując jednak wyjątek przewidziany dla opłat zryczałtowanych ponoszonych $\mathrm{w}$ związku $\mathrm{z}$ odprowadzaniem ścieków $\mathrm{z}$ chowu lub hodowli ryb innych niż łososiowate. Końcowa data określona wspólnie dla wszystkich sposobów korzystania ze środowiska wyznaczona została na dzień 31 marca roku następującego po roku kalendarzowym, w którym rozpoczęto korzystanie ze środowiska, również w sytuacji, gdy w danym roku kalendarzowym na składowisku odpadów umieszczono odpady oraz wydobyto $\mathrm{z}$ niego odpady tego samego rodzaju. W tym wypadku założone przez ustawodawcę ograniczenie obciążenia przedsiębiorców świadczeniami publicznymi przyjęło więc postać przekształcenia dwukrotnego, bo dokonywanego po każdym półroczu obowiązku ponoszenia opłat na rzecz jednorazowego ich uiszczania w wysokości odzwierciedlającej cały zakres korzystania ze środowiska w poprzednim roku kalendarzowym.

Uważna analiza przepisów związanych z obowiązkiem opłatowym skłania jednak ku twierdzeniu, iż wprowadzone zmiany zakładające ograniczenie uciążliwych i zbędnych obciążeń administracyjnych przedsiębiorców korzystających ze środowiska nie spełniły swojej roli. Wręcz przeciwnie, chęć uproszczenia przepisów $\mathrm{w}$ praktyce spowodowała jedynie ich skomplikowanie, powiększając tym samym bariery rozwoju

34 Art. 6 ustawy z dnia 13 kwietnia 2012 r. o zmianie ustawy - Prawo ochrony środowiska oraz niektórych innych ustaw, Dz.U. z 2012 r., poz. 460, dalej jako: UZm3. 
przedsiębiorczości. Wydaje się bowiem, że ostatnie modyfikacje, pomimo doświadczenia uzyskanego nabytego w toku prac nad dwiema wcześniejszymi ustawami deregulacynymi, zostały dokonane bez niezbędnej, wnikliwej analizy istniejących już przepisów, i wprowadzają zapewne niezamierzony, ale jednak bałagan legislacyjny.

Jest to następstwem braku skoordynowania podjętych przez ustawodawcę działań z założeniami dokonanych uprzednio nowelizacji. Uchwalone zmiany zdają się bowiem nie uwzględniać przewidzianego w ustawie o systemie zarządzania emisjami zastrzeżenia wskazującego, iż do opłat za wprowadzanie gazów lub pyłów do powietrza należnych do dnia 31 grudnia 2010 (art. $15 \mathrm{UZm1}$ ), przedłużany następnie do 31 grudnia 2012 r. (art. 2 UZm2) i 31 grudnia 2016 r. (art. 6 UZm3) stosuje się przepisy art. 285-288 POŚ w ich brzmieniu sprzed wejścia w życie USZE, a zatem obowiązujące w wersji sprzed 18 września 2009 r., przewidujące co do zasady jednolite, półroczne opłaty za korzystanie ze środowiska, wnoszone do końca miesiąca następującego po upływie każdego półrocza.

Wskutek tego można zatem uznać, iż od początku stycznia 2013 r. w prawie ochrony środowiska funkcjonują dwa równoległe systemy przepisów dotyczących opłat za korzystanie ze środowiska. Z jednej strony, zgodnie z założeniami nowelizacji dokonanej przepisami ustawy o systemie zarządzania emisjami, podmiot obciążony obowiązkiem opłatowym, niezależnie od postaci korzystania ze środowiska, wnosi opłatę za cały rok kalendarzowy do dnia 31 marca każdego roku. Z drugiej zaś, w myśl normy zawartej w art. 60a ust. 1 USZE, do końca 2016 r. podmiot wprowadzający gazy lub pyły do powietrza powinien wnosić opłatę w dwóch terminach: do 31 stycznia oraz 31 lipca, wyliczoną odrębnie dla każdego półrocza, w którym rozpoczęto korzystanie ze środowiska.

Należy również pamiętać, że zgodnie z art. 62 USZE przewidziane nią zmiany $\mathrm{w}$ brzmieniu art. 285-286 POŚ wejdą w życie z dniem 1 stycznia 2017 r. Od tego też czasu system ponoszenia opłat środowiskowych powróci na nowo do formy półrocznych opłat za korzystanie ze środowiska z tytułu wpro2/2013 wadzania ścieków do wód lub do ziemi, poboru wód oraz skła- 
dowania odpadów. W przypadku zaś wprowadzania gazów lub pyłów do powietrza, opłaty ponoszone będą pierwszy raz niejako tylko zaliczkowo, do końca miesiąca następującego po upływie pierwszego półrocza, w wysokości 50\% rocznej opłaty za emisję do powietrza uiszczoną w poprzednim roku kalendarzowym, a zasadnicza część opłaty będzie musiała zostać ostatecznie wniesiona do końca lutego roku następnego za drugie półrocze, w kwocie pomniejszonej o wysokość opłaty uiszczonej za pierwsze półrocze.

Niezależnie od tego zastanawiające wydaje się również to, czy wprowadzenie jednorazowej opłaty naliczanej z tytułu korzystania ze środowiska za cały rok stanowi faktycznie formę odciążenia administracyjnego przedsiębiorców. Przyjęta formuła ogranicza wprawdzie obowiązki przedsiębiorcy związane z dokonywanym półrocznie obliczaniem oraz faktycznym ponoszeniem $\mathrm{w}$ tym terminie opłat środowiskowych, wymuszając jednak równocześnie konieczność zarezerwowania w budżecie przedsiębiorstwa jednorazowo znacznie większej sumy pieniężnej na pokrycie świadczenia publicznego i ograniczając tym samym możliwość inwestowania wolnych środków finansowych, a tym samym i rozwoju przedsiębiorstwa.

\section{REDUKCJA NIEKTÓRYCH OBCIĄŻEŃ WYNIKAJĄCYCH Z OBOWIĄZKÓW INFORMACYJNYCH}

Zgoła odmienne skutki zdają się wywoływać zmiany regulacji przewidujących ograniczenie obowiązków informacyjnych. Przepisy prawa nakładają na podmioty korzystające ze środowiska obowiązek prowadzenia aktualizowanych okresowo ewidencji zawierających informacje dotyczące profilu prowadzonej działalności oraz skali wykorzystania i następującego w jej toku oddziaływania na poszczególne elementy przyrodnicze. Uzasadnione jest to względami prawidłowości funkcjonowania systemu opłatowego, gdyż wobec przerzucenia ciężaru ustalenia wysokości opłaty i wniesienia jej we właściwym terminie na podmiot korzystający ze środowiska istnieje konieczność do- 
konywanej przez organ administracji weryfikacji tego rodzaju czynności ${ }^{35}$. Dlatego obowiązujące przed zmianami przepisy art. 287 ust. 1 pkt $1-5$ POŚ w sposób wyraźny podkreślały, że podmiot korzystający ze środowiska powinien prowadzić aktualizowaną co pół roku ewidencję, zawierającą odpowiednio do rodzaju korzystania ze środowiska informacje o: ilości i rodzajach gazów lub pyłów wprowadzanych do powietrza oraz dane, na podstawie których określono te ilości, ilości i jakości pobranej wody powierzchniowej i podziemnej, ilości, stanie i składzie ścieków wprowadzanych do wód lub do ziemi, wielkości, rodzaju i sposobie zagospodarowania terenu, z którego odprowadzane są ścieki, a także wielkości produkcji ryb innych niż łososiowate lub innych organizmów wodnych oraz powierzchni użytkowej stawów eksploatowanych w cyklu produkcyjnym w obiektach chowu lub hodowli tych ryb lub tych organizmów, za okres od 1 maja roku rozpoczynającego cykl do 30 kwietnia roku następującego po zakończeniu tego cyklu produkcyjnego. Zasady prowadzenia ewidencji odpadów zostały natomiast określone przez odrębne przepisy (art. 287 ust. 2 POŚ) ${ }^{36}$.

Dane te, w postaci stosownych wykazów i sprawozdań, podmiot korzystający ze środowiska był zobowiązany wraz z należną opłatą przekazywać dwa razy do roku, do końca lipca za pierwsze półrocze oraz do końca stycznia kolejnego roku za drugie półrocze, organowi ochrony środowiska właściwemu ze względu na sposób i miejsce korzystania ze środowiska - Marszałkowi województwa. Wykaz zawierający informacje i dane wskazane w art. 287 ust. 1 pkt 1-3 POŚ wykorzystane do ustalenia wysokości stosownych opłat podmiot korzystający ze środowiska przekazywał również wojewódzkiemu inspektorowi ochrony środowiska, a w przypadku wykazu zawierającego informacje stanowiące podstawę dla ustalenia wysokości opłaty za składowanie odpadów także Wójtowi, Burmistrzowi lub Prezydentowi miasta właściwemu ze względu na miejsce ich

35 A. Lipiński, Prawne podstawy ochrony środowiska, Warszawa 2010, s. 332 .

36 Dotyczą ich przepisy działu V ustawy z dnia 14 grudnia 2012 r. o odpadach, Dz.U. z 2013 r., poz. 21. 
składowania. Wzór wykazu określony został przepisami rozporządzenia wykonawczego ${ }^{37}$. Tak uzyskane informacje, oprócz możliwości kontroli procesu wnoszenia opłat, należy również uznać za istotne narzędzie wykorzystywane w ramach państwowego monitoringu środowiska ${ }^{38}$.

Już 18 września 2009 r., wraz z początkiem obowiązywania ustawy o systemie zarządzania emisjami, uchylony został przepis art. 287 ust. pkt 1 POŚ, zobowiązujący podmiot dokonujący emisji gazów lub pyłów do powietrza do prowadzenia stosownej ewidencji swojej działalności. Kolejnym zaś modyfikacjom przepisy art. 286-287 POŚ związane z obowiązkami informacyjnymi podmiotów korzystających ze środowiska uległy z chwilą wejścia w życie ustawy o redukcji niektórych obciążeń administracyjnych w gospodarce. Po wniesionych zmianach podmiot korzystający ze środowiska powinien prowadzić ewidencję zawierającą informacje o dokonywanym w danym roku kalendarzowym poborze wód, wprowadzaniu ścieków do wód lub do ziemi, składowaniu odpadów oraz produkcji ryb innych niż łososiowate lub innych organizmów wodnych. Jest on przy tym zobowiązany do przedkładania marszałkowi województwa przygotowanych na podstawie prowadzonej ewidencji wykazów, zawierających informacje i dane wykorzystane do ustalenia wysokości opłat oraz wysokość tych opłat, w ujednoliconym terminie do 31 marca roku następującego po roku, w którym miało miejsce korzystanie ze środowiska (art. 286 ust. 1 POŚ) ${ }^{39}$. Natomiast przekazanie stosownych wykazów właściwemu wojewódzkiemu inspektorowi ochrony środowiska oraz Wójtowi,

37 Rozporządzenie Ministra Środowiska z dnia 18 czerwca 2009 r. w sprawie wzorów wykazów zawierających informacje i dane o zakresie korzystania ze środowiska oraz o wysokości należnych opłat, Dz.U. Nr 97, poz. 816.

38 K. Gruszecki, Komentarz do art. 286 ustawy - Prawo ochrony środowiska, [w:] Prawo ochrony środowiska. Komentarz, red. K. Gruszecki, Lex nr 107248.

39 Wyjątkiem pozostaje obowiązek podmiotu korzystającego ze środowiska odprowadzania ścieków pochodzących z chowu lub hodowli ryb innych niż łososiowate lub innych organizmów wodnych, który przekazuje informacje do końca miesiąca następującego po zakończeniu cyklu produkcyjnego, rozpoczynającego się 1 maja i kończącego się 30 kwietnia następnego roku (art. 286 ust. 1a POŚ). 
Burmistrzowi lub Prezydentowi miasta przypisane zostało już do obowiązków marszałka województwa, obciążając go związanymi z tym kosztami (art. 287 ust. 1b i 2 POŚ).

Uzasadnieniem dla wprowadzonych zmian była przede wszystkim chęć ograniczenia nałożonych na przedsiębiorców uciążliwych i nadmiernych obowiązków, także tych o informacyjnym charakterze, a pośrednio również ułatwienia kontaktów podmiotów korzystających ze środowiska z poszczególnymi organami administracji. Ustawodawca poprzez swe działania chciał dać również wyraz zaufania państwa do przedsiębiorców. Zmniejszenie części obciążeń administracyjnych miało także ograniczyć koszty dopełniania procedur administracyjnych, a tym samym i koszty wykonywania samej działalności gospodarczej $^{40}$. O ile jednak wola ograniczenia niepotrzebnych obciążeń regulacyjnych związanych z obowiązkami informacyjnymi powinna stać się priorytetem polskiego prawodawcy i zasługuje na uznanie, o tyle również i w tym zakresie działań ustawodawcy doszukać się można pewnych dysfunkcjonalności.

Zauważyć bowiem należy, iż od 1 stycznia 2013 r. przepisy rangi ustawowej nie przewidują już wymogu prowadzenia ewidencji wprowadzanych gazów lub pyłów do powietrza, będących podstawą przygotowywania dotychczasowych wykazów i dokumentujących wysokość ustalonych opłat środowiskowych. Wprawdzie obowiązek ten zastąpiony został koniecznością sporządzania przez podmiot korzystający ze środowiska rocznego raportu (art. 7 USZE), obejmującego między innymi informacje o wielkościach emisji gazów cieplarnianych i innych substancji wprowadzanych do powietrza, czy wielkościach produkcji, charakterystyce surowców i paliw towarzyszących emisjom, i wprowadzania go do końca lutego każdego roku do „Krajowej bazy o emisjach gazów cieplarnianych i innych substancji”, jednakże ich zakres nie jest tożsamy. Podmiot korzystający ze środowiska zobligowany jest jedynie do wprowadzenia pewnych danych koniecznych z punktu widzenia funkcjonowania systemu zarządzania emisjami, a nie prowadzenia dokumentacji potwierdzającej ich wiarygodność. Niedostatki w obowiązujących przepi-

40 Uzasadnienie projektu ustawy. 
sach uniemożliwiają również wymierzenie kary za popełnione wykroczenie związane $\mathrm{z}$ brakiem stosownej ewidencji prowadzonej działalności (art. 359 POŚ). Dlatego też wydaje się, że wprowadzone zmiany mogą w znacznym stopniu utrudnić weryfikację przedstawianych wielkości emisji i tym samym kontrolę wysokości należnej opłaty za dokonaną rzeczywistą emisję ${ }^{41}$.

Co więcej, w braku korekty aktualnego brzmienia obowiązujących przepisów, wraz z początkiem 2017 r. nastąpi nieprzewidziane przemieszanie zmian przepisów dokonywanych obiema nowelizacjami. Doprowadzić to może do sytuacji, w której podmiot korzystający ze środowiska i obciążony obowiązkiem uiszczania opłat środowiskowych za każde półrocze zobowiązany będzie do prowadzenia aktualizowanej jedynie rocznie ewidencji (art. 287 ust. 1 POŚ w brzmieniu ustalonym UROA). Dodatkowo, niezamierzone przez prawodawcę skutki mogą się także wiązać z utrzymaniem $\mathrm{w}$ mocy przepisu zwalniającego z aktualizującego się co pół roku obowiązku opłatowego w przypadku, kiedy to roczna wysokość opłaty nie przekroczy $800 \mathrm{zł}$ (art. 289 ust. 1 POŚ w brzmieniu nadanym UROA). Regulacja ta, pomimo trudnych do sprecyzowania praktycznych konsekwencji jej wprowadzenia, z pewnością nie ułatwi stosowania przepisów podmiotom korzystającym ze środowiska.

\section{PODSUMOWANIE}

Przedstawione rozważania dotyczące oceny stopnia realizacji założonego przez prawodawcę celu ograniczenia niektórych obciążeń administracyjnych $\mathrm{w}$ gospodarce $\mathrm{w}$ drodze nowelizacji przepisów prawa dotyczących opłat środowiskowych i obowiązków informacyjnych, oparte wprawdzie jedynie na wycinku obszaru podlegającego regulacji, skłaniają do refleksji nad ogólnym poziomem legislacji, a w szczególności nad jej stanem w dziedzinie prawa ochrony środowiska. Przyjęte w ostat-

41 M. Jóźwiak, Zanieczyszczający płaci, „Ecomanager” 2011, nr 4, s. 31. 
nim czasie przepisy uświadamiają bowiem nie tylko stopień i dynamikę dokonywanych zmian, ale i wynikający zapewne z chęci osiągnięcia doraźnych i wąsko rozumianych celów brak ich uporządkowania, czy wręcz chaotyczność. Konsekwencją tego faktu jest postępująca, systematyczna dekonsolidacja całego systemu regulacji.

Dlatego też, pomimo iż podejmowane przez ustawodawcę wysiłki na rzecz redukcji nadmiernych obciążeń administracyjnych, nie tylko tych biurokratycznych, ale i finansowych, należy ocenić pozytywnie, to jednak wobec dokonanych ostatnio nowelizacji należałoby się zastanowić nad kierunkiem, zasadnością oraz realnymi skutkami zmian poszczególnych przepisów. Wysoki stopień skomplikowania, jak i dynamika przemian poszczególnych grup przepisów zdają się bowiem dość wyraźnie odstawać od standardów konstytucyjnej zasady państwa prawa, a zwłaszcza wyznaczonych nią podstawowych zasad prawidłowej legislacji ${ }^{42}$. Uwaga ta w sposób szczególny odnosi się do zasady określoności przepisów prawa, rozumianej jako obowiązek formułowania przepisów w sposób poprawny, precyzyjny i jasny, tak by ich adresat mógł bez trudu określić wynikające z nich konsekwencje prawne ${ }^{43}$. Tak jak planowanie zamierzonej działalności legislacyjnej jest warunkiem uznania racjonalności działann ${ }^{44}$, tak i poprawność redakcji tekstu prawnego jest przecież podstawowym warunkiem prawidłowości procesów wykładni, stosowania i przestrzegania prawa ${ }^{45}$.

Analiza zmian w przepisach dotyczących opłat za korzystanie ze środowiskiem i związanych z nimi obowiązków informacyjnych nie rozwiewa jednak szeregu pojawiających się w tym zakresie praktycznych wątpliwości. Co więcej, istnieje

42 T. Zalasiński, Zasada prawidłowej legislacji w poglądach Trybunału Konstytucyjnego, Warszawa 2008, s. 51.

${ }^{43}$ L. Garlicki, Orzecznictwo Trybunału Konstytucyjnego, „Przegląd Sejmowy" 1999, nr 6, s. 124.

44 T. Zalasiński, Planowanie działalności legislacyjnej Rady Ministrów stan obecny i proponowane kierunki zmian, [w:] Jak poprawić rzadzenie Polska w XXI wieku? V Kongres Obywatelski, Gdańsk 2010, s. 19.

45 M. Bogusz, Problem charakteru prawnego zasad techniki prawodawczej, „Gdańskie Studia Prawnicze” 2010, nr 2, s. 91. 
ryzyko, że faktyczni adresaci przyjętych norm zmuszeni będą działać w warunkach niepewności zarówno co do faktycznych podstaw prawnych, jak i poprawności stosowanych przepisów. Tym trudniej jest w tym wypadku doszukiwać się racjonalności w działaniach polskiego prawodawcy.

\section{BIBLIOGRAFIA}

Bogusz M., Problem charakteru prawnego zasad techniki prawodawczej, „Gdańskie Studia Prawnicze” 2010, nr 2.

Bukowski Z., Dysharmonizacja polskiego prawa ochrony środowiska z prawem unijnym na wybranych przyktadach, [w:] Dekada harmonizacji $w$ prawie ochrony środowiska, red. M. Rudnicki, A. Haładyj, K. Sobieraj, Lublin 2011.

Czech T., Odpowiedzialność za opłaty podwyższone za korzystanie ze środowiska, „Zeszyty Naukowe Sądownictwa Administracyjnego" 2009, nr 6.

Draniewicz B., Opłaty za korzystanie ze środowiska. Zarys analizy płaszczyzny prawnej, „Prawo i Środowisko” 2002, nr 1.

Draniewicz B., Problem konstytucyjności opłat za korzystanie ze środowiska, „Państwo i Prawo 2007”, nr 7.

Duniewska Z., W kwestii czynników kształtujących prawo administracyjne, [w:] Między tradycją a przyszłościa $w$ nauce prawa administracyjnego. Księga jubileuszowa dedykowana Profesorowi Janowi Bociowi, Wrocław 2009.

Fill W., Charakter prawny opłat za korzystanie ze środowiska, [w:] Główne wyzwania i problemy systemu finansów publicznych, red. J. Głuchowski, A. Pomorska, J. Szołno-Koguc, Lublin 2009.

Garlicki L., Orzecznictwo Trybunału Konstytucyjnego, „Przegląd Sejmowy" 1999, nr 6.

Górski M., [w:] Prawo ochrony środowiska, red. M. Górski, Warszawa 2009.

Górski M., System organizacyjny administrowania sprawami ochrony środowiska $w$ Polsce - analiza krytyczna, [w:] Ocena modelu organizacji ochrony środowiska $w$ Polsce i na Stowacji, red. E. Ura, J. Stelmasiak, S. Pieprzny.

Gruszecki K., Komentarz do art. 286 ustawy - Prawo ochrony środowiska, [w:] Prawo ochrony środowiska. Komentarz, red. K. Gruszecki, Lex nr 107248. 
Gruszecki K., Opłaty za korzystanie ze środowiska $w$ prawie ochrony środowiska, „Glosa” 2003, nr 7.

Haładyj A., Czy prawo ochrony środowiska jest odrębna gałęzia prawa?, [w:] Historia magistra vitae. Ksiegga jubileuszowa ku czci Profesora Jerzego Flagi, red. A. Dębiński, S. Wrzosek, K. Maćkowska, M. Kruszewska-Gagoś, Lublin 2007.

Haładyj A., O nadmiarze i braku w zakresie prawnej regulacji udziału społeczeństwa w ochronie środowiska, [w:] Kryzys prawa administracyjnego? Inflacja prawa administracyjnego, red. D. Kijowski, P. J. Suwaj, Warszawa 2012.

Haładyj A., Sobieraj K., Uwagi na 30-lecie prawa ochrony środowiska, [w:] Prawo dla środowiska, red. A. Erechemla, Rzeszów 2011.

Jóźwiak M., Zanieczyszczający płaci, „Ecomanager” 2011, nr 4.

Lipiński A., Prawne podstawy ochrony środowiska, Warszawa 2010.

Małecki J., Prawnofinansowe instrumenty ochrony i ksztattowania środowiska, Poznań 1982.

Rakoczy B., Ustawa o udostępnianiu informacji o środowisku a koncepcja legislacyjna polskiego prawa ochrony środowiska, „Prawo i Środowisko" 2009, nr 1.

Sommer J., Efektywność prawa ochrony środowiska i jej uwarunkowania - problemy udatności jego struktury, Wrocław 2005.

Suwaj P. J., O globalnym prawie administracyjnym $w$ kontekście rozrostu prawa administracyjnego, [w:] Kryzys prawa administracyjnego? Inflacja prawa administracyjnego, red. D. Kijowski, P. J. Suwaj, Warszawa 2012.

Wierzbowski B., Rakoczy B., Prawo ochrony środowiska. Zagadnienia podstawowe, Warszawa 2010.

Zalasiński T., Planowanie działalności legislacyjnej Rady Ministrów stan obecny i proponowane kierunki zmian, [w:] Jak poprawić rządzenie Polskq w XXI wieku? V Kongres Obywatelski, Gdańsk 2010.

Zalasiński T., Zasada prawidłowej legislacji w poglądach Trybunału Konstytucyjnego, Warszawa 2008.

Zimmermann J., Jedność prawa administracyjnego, [w:] Między tradycją a przyszłością $w$ nauce prawa administracyjnego. Księga jubileuszowa dedykowana Profesorowi Janowi Bociowi, red. J. Supernat, Wrocław 2009.

Kontakt e-mail:

trzewik@kul.pl 